\title{
Evaluation of dentistry students' knowledge on hematologic disorders
}

\author{
Avaliação do conhecimento de estudantes de Odontologia acerca dos distúrbios hematológicos
}

Camila Anselmo da SILVA ${ }^{1}$

Cláudio Leite de SANTANA ${ }^{1}$

Rita de Cássia Dias Viana ANDRADE ${ }^{1}$

Taís de Lima e FRAGA ${ }^{1}$

Fabio Ornellas PRADO'

\section{ABSTRACT}

\section{Objective}

To determine the knowledge level of undergraduate dentistry students of UESB on hematological disorders and their implications in the treatment of the patient.

\section{Methods}

This is a descriptive, quantitative and cross-sectional study in which a questionnaire with 16 questions was used as a data collection instrument The study subjects were 192 students enrolled at UESB Dentistry Course. For data analysis, SPSS statistical software (version 16.0) was used.

\section{Results}

The response rate was $87.5 \%$. Only $54.2 \%$ of respondents reported having information about blood disorders and $78 \%$ considered themselves not enough informed, fact observed through the low percentage of right answers in a knowledge test.

\section{Conclusion}

The level of knowledge of UESB Dentistry academics on hematological disorders is insufficient and there isn't a gradual increment of this knowledge throughout the semesters, polarized mainly in the 6th and 10th semester.

Indexing terms: Anemia, sickle cell. Hemophilia A. Hemophilia B. Knowledge. Leukemia. Students dental.

\section{RESUMO}

\section{Objetivo}

Verificar o nível de conhecimento de graduandos do curso de Odontologia da UESB sobre os distúrbios hematológicos e suas implicações para o tratamento do paciente em âmbito odontológico.

\section{Métodos}

Trata-se de um estudo descritivo, quantitativo e de corte transversal, onde adotou-se como instrumento de coleta de dados um questionário, composto por 16 perguntas. Os sujeitos da pesquisa foram os 192 estudantes regularmente matriculados no curso de Odontologia da UESB. Para análise dos dados foi utilizado o software estatístico SPSS (versão 16.0).

\section{Resultados}

A taxa de resposta foi de $87,5 \%$. Apenas $54,2 \%$ dos entrevistados relataram ter informações acerca dos distúrbios hematológicos e $78 \%$ consideraram-se insuficientemente informados, fato corroborado pelas baixas porcentagens de acertos nos testes de conhecimento.

\section{Conclusão}

O nível de conhecimento dos acadêmicos de Odontologia da UESB sobre os distúrbios hematológicos mostrou-se insuficiente e não houve um crescimento gradual deste conhecimento ao longo dos semestres, estando o mesmo polarizado principalmente nos $6^{\circ}$ e $10^{\circ}$ semestres.

Termos de indexação: Anemia falciforme. Hemofilia A. Hemofilia B. Leucemia. Conhecimento. Estudantes de Odontologia.

\footnotetext{
${ }^{1}$ Universidade Estadual do Sudoeste da Bahia, Faculdade de Odontologia, Departamento de Saúde. Av. José Moreira Sobrinho, s/n., Jequiezinho, 45206-510, Jequié, BA, Brasil. Correspondência para / Correspondecen to: FO PRADO. E-mail: <fop_@hotmail.com>.
} 


\section{INTRODUCTION}

Hemopathies or hematological disfunctions are constituted of a group of diseases related to blood that can present a number of different etiologies and clinical features. They may be classified as anemia, coagulopathies, and malignant blood diseases ${ }^{1}$.

Some of these disfunctions present buccal and/ or maxillofacial manifestations that are directly related to the surgeon-dentist working field. Given the prevalence within each group, sickle cell anemia, hemophilia and leukemia are prominent.

Sickle cell anemia is one of the most common hereditary pathologies in Brazil. It is estimated that about 3,550 children are born per year with falciform disease and 200,000 trace bearers. Such scenario calls for this pathology to be treated as a public health issue ${ }^{2}$.

Leukemia is the most common malignant disease in infancy, corresponding approximately to $30 \%$ of cancer cases in children. In Brazil, the estimate for 2016 is 10,070 new cases $^{3}$.

According to the Brazilian Federation of Hemophilia, Brazil is the third largest population worldwide of patients with hereditary genetic disorders with 9,122 cases of Hemophilia $A ; 1,801$ cases of Hemophilia B; 5,445 cases of Von Willebrand and 1,851 of other hereditary hemorrhagic coagulopathies. Hemophilia incidence is one case for each 5.000 males born alive ${ }^{4}$.

Given what was stated above, it must be highlighted that in addition to such pathologies, typical buccal manifestations, dental procedures are able to exude blood, a number of medications must be administered with restriction in such patients. Thus, it is fundamentally important knowledge diffusion with regards to hematologic disfunctions even in the undergraduate level, since these patients must receive special attention in accordance with their health status. Moreover, the current literature doesn't offer studies similar to the current study, which keeps knowledge from teaching reality with regards to this theme.

The objective of this paper was to verify the knowledge level of Dentistry students at the Southwest Bahia State University (UESB) with regards to the approach of hematological disfunctions and its interference in Dentistry and to identify the mode of operating of information diffusion.

\section{METHODS}

A transversal quantitative descriptive research was performed. The study sample was the student body of the Course of Dentistry at UESB with 192 students regularly enrolled in the period of 2013.2 and disposed in 10 semesters that integrate the course.

The data collection instrument was a questionary divided in three blocks. Block I: containing three questions regarding identification (age, gender and attending semester). Block II: containing ten questions regarding knowledge of hematological disfunctions and their interference in Dentistry, and how information was obtained. Block III: containing one question regarding transmission of information by the professor of the course, whether there is or not. If the answer is affirmative, which transmission form was employed?

Data collection was carried out during September and October 2013. It was initiated only after the research project approval by the Ethics in Research Committee of UESB (protocol 365.284, CAAE: 19707913.8.0000.0055). The research subjects were approached in the class room. Prior to answering the questionary, objectives and procedures of the study were explained, and the Free and Clarified Consent Term (TCLE) was signed.

Descriptive statistics (relative and absolute frequency) was employed in the data analysis. Data were analyzed with statistic software: Statistical Package for the Social Sciences - SPSS (version 16.0).

\section{RESULTS}

Among the 192 regularly enrolled academics, 168 accepted to participate in this research, that represents a response rate of $87.5 \%$. In the group that joined the research, $65.5 \%$ were females and $61.3 \%$ were in the agegroup from 21 to 25 years.

When asked if they were aware of implications of hematologic disorders in Dentistry, $54.1 \%(n=91)$ of academics asserted that they were partially informed. On the other hand, $45.8 \%$ informed that they had not obtain this information yet; $70 \%(n=54)$ pointed out as a motive the lack of opportunity; $0.7 \%(n=1)$ were not interested in the subject and $29 \%(n=22)$ other reasons. Most students that indicated 'other' as to the reason of their unfamiliarity believe that the content will be approached in the next semesters. Among those who had some information, the majority (78\%) considered themselves insufficiently informed about the theme; $22 \%$ sufficiently informed and none were fully informed, as shown in Figure 1.

Regarding hemophilia characteristics, only $27.4 \%$ $(n=46)$ of academics have knowledge of the theme. Students 
who obtained better results were attending the tenth (75\%, $n=12)$, sixth $(52.6 \%, n=10)$, fifth $(37.5 \%, n=6)$, eighth $(31.2 \%, n=5)$ and seventh $(29.2 \%, n=7)$ semesters. The lowest indices of correct answers were observed in the ninth $(14.3 \%, n=2)$ and fourth (14.3\%, $n=2)$, third $(11.1 \% n=2)$, first and second $(0 \% n=0)$ semesters.

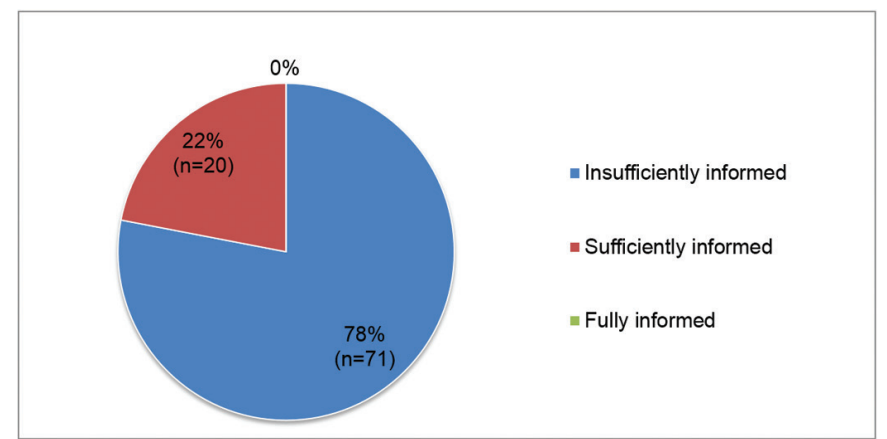

Figure 1. Perception of the knowledge level regarding hematologic dysfunctions Jequié, 2013

As for leukemia characteristics, $27.9 \%(n=47)$ of graduands know the content, whereas the first $(n=0)$ and second $(n=0)$ semesters $(0 \%)$, third $(11.1 \%, n=2)$, fourth $(35.7 \%, n=5)$, fifth $(25 \%, n=4)$, sixth $(68.4 \%, n=13)$, seventh $(20.8 \%, n=5)$, eight $(25 \%, n=4)$, ninth $(28,6 \%, n=4)$ and tenth $(62.5 \%, \mathrm{n}=10)$.

Concerning sickle cell anemia, $44.0 \%(n=74)$ of the students solved the question, $0 \%$ of the first $(n=0)$ and second $(n=0)$ semesters, $27.8 \%(n=5)$ third, 64.3\% $(n=9)$ forth, $56.2 \%(n=9)$ fifth, $68.4 \%(n=13)$ sixth, 50\%, seventh $(n=12)$ and eighth ( $n=8), 35.7 \%(n=5)$ ninth, $81.2 \%$ $(n=13)$ tenth, semesters. Comparison of correct answers per semester can be analyzed in Figure 2.

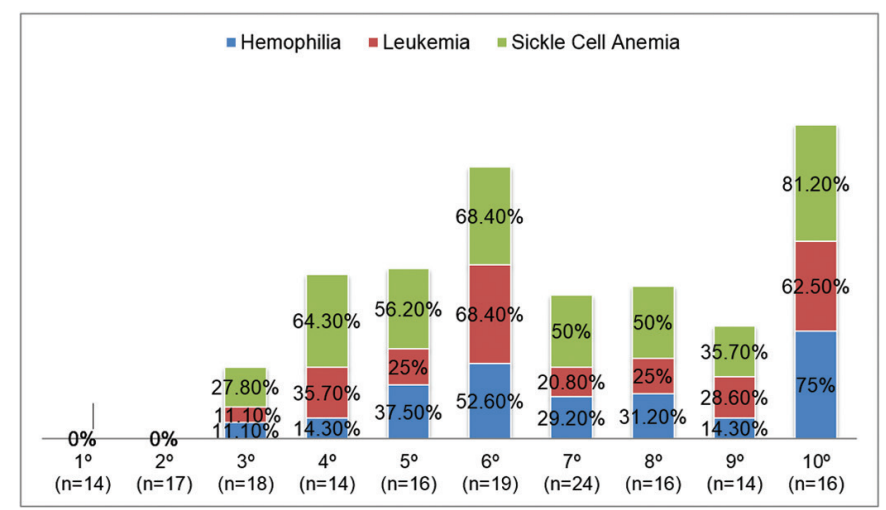

Figure 2. Knowledge of etiology of hematologic dysfunctions Jequié 2013.
In relation to odontological complications caused by hemophilia $38.1 \%(n=64)$ of the respondents totality marked the correct option $0 \%$ in the first $(n=0)$ and second $(n=0)$ semesters, $22.2 \%(n=4)$ in the third, 35,7\% $(n=5)$ in the fourth, $43.8 \%(n=7)$ in the fifth, $78.9 \%(n=15)$ in the sixth, 29.2\% (n=7) in the seventh, $62.5 \%(n=10)$ in the eighth, $21.4 \%(n=3)$ in the ninth and $81.2 \%(n=13)$ in the tenth.

Odontological complications caused by leukemia were correctly indicated by $26.2 \%(n=44)$ of the research subjects with, $0 \%(n=0)$ in the first, $5.9 \%(n=1)$ in the second, $5.6 \%(n=1)$ in the third, $7.1 \%$ in the fourth $(n=1)$, $37.5 \%(n=6)$ in the fifth, $52.6 \%(n=10)$ in the sixth, 33.3\% $(n=8)$ in the seventh, $25 \%$ in the eighth $(n=4), 28.6 \%$ $(n=4)$ in the ninth and $56.2 \%(n=9)$ in the tenth semester.

With regards to odontological complications caused by sickle cell anemia, 30.4\% ( $n=51)$ marked the correct answer with $0 \%(n=0)$ in the first, $11.2 \%(n=2)$ in the second, $22.2 \%(n=4)$ in the third, 35.7\% $(n=5)$ in the fourth, $31.2 \%(n=5)$ in the fifth, $42.1 \%(n=8)$ in the sixth $29.2 \%(n=7)$ in the seventh, 31.2\% $(n=5)$ in the eighth, 35.7\% $(n=5)$ in the ninth, and $62.5 \%(n=10)$ in the tenth semester. The data about knowledge of buccal complications of hematologic dysfunctions are shown in Figure 3.

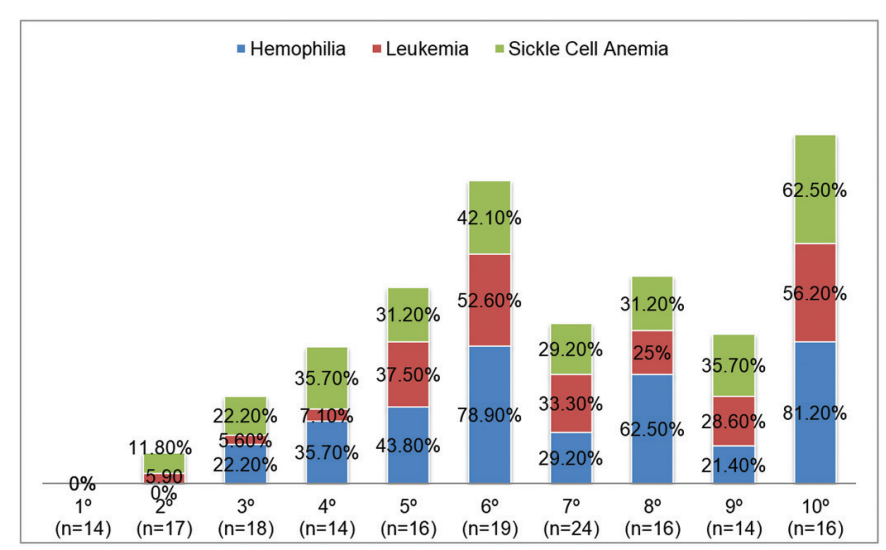

Figure 3. Knowledge of odontological complications of hematologic dysfunctions per semester. Jequié, 2013.

When questioned about the exams that must be prescribed in order to evaluate the patient condition with abnormal bleeding after any cut or surgery, $31.5 \%$ of the academics marked the correct option.

In relation to the means to obtain information about hematologic dysfunctions and their implication in Dentistry, $67 \%$ of the students indicated classes, 
$4 \%$ scientific events about several themes or Dentistry specialties, $9 \%$ the internet, $18 \%$ a combination of these factors and $2 \%$ other sources, in which books was the most cited. Those who marked classes cited the following disciplines: Oral Diagnostic (DO) (30\%), Odontological Clinic I (CO I) (28\%), Integrated Clinic IV (CI-IV) (16\%), Histology (9\%), Biochemistry (7\%), Pathology (6\%) and Physiology (4\%) (Figures 4 and 5).

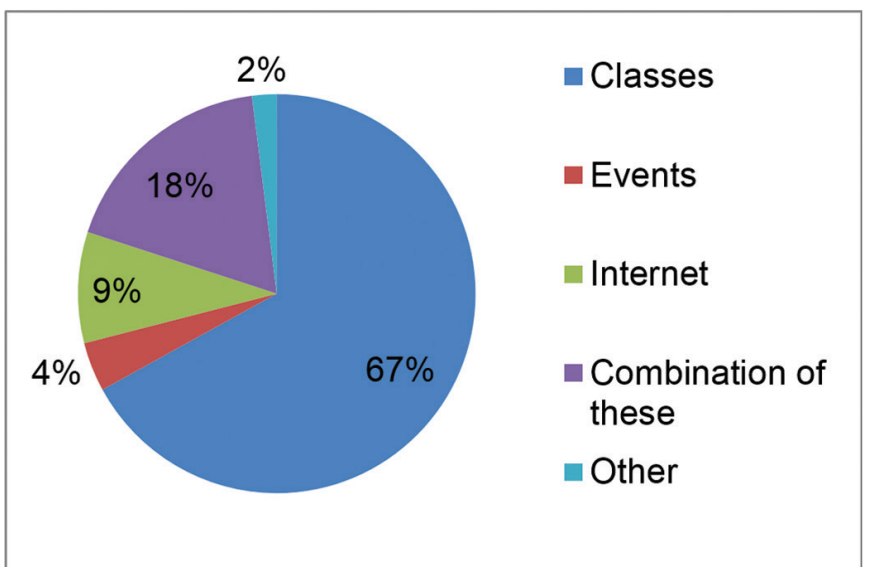

Figure 4. Means to obtain information about hematologic dysfunctions Jequié, 2013

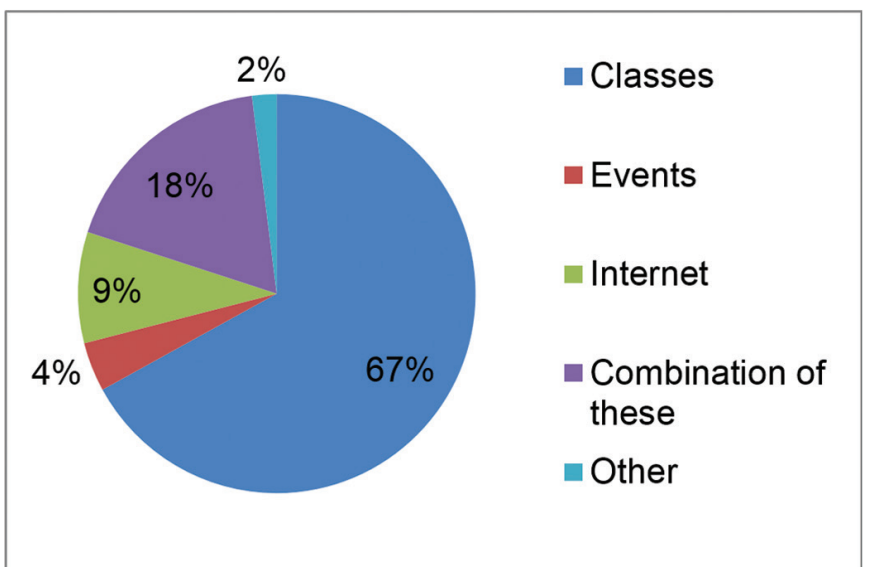

Figure 5. Disciplines that approach contents.about hematologic dysfunctions Jequié, 2013.

When asked if the professors have the habit to inform hematologic dysfunctions and their implication in Dentistry, $35.1 \%$ said no, $48.2 \%$ indicated yes, only in the specific area of the discipline content and $16.7 \%$ marked yes in a general manner in their commitment in procedures of several specialties.

According to the graduands who marked positively, $8 \%$ indicated that the professors stimulate article readings about hematologic dysfunction and its implication in
Dentistry; 66\% appointed that during classes they were told about the possibility of complications caused by these dysfunctions; 8\% asserted that they comment about hematologic dysfunction. They also own/suggest didactic material which informs odontological complications, as well as attending protocol for patients presenting hematologic alterations and $18 \%$ marked a combination of these options.

Within the academics group who marked negatively, $12 \%$ believe that the subject is distant from graduation reality; $63 \%$ believe that the information is intended to a specific discipline; $2 \%$ think that the information is disposable, given that these informations are dispensable due to its low practical utility; and 23\% marked other reasons. Among the latter, some believe that this content will be approached in posterior semesters and others pointed the need to adapt the course curricular adequateness, so that this theme be adapted in order to the theme be contemplated.

\section{DISCUSSION}

Sickle cell anemia is a hereditary chronic hemolytic disease ${ }^{5}$ caused by a punctual mutation of chromosome 11 . As a result, the substitution of glutamic acid by valine in the position 6 of the $\beta$ hemoglobin chain originates hemoglobin $S^{6}$. This structural alteration is accountable for the modification in stability, solubility and erythrocyte structure. The latter, in hypoxia conditions, assume a form similar to a sickle. Thereof, the word sickle derived from polymerization of hemoglobin $\mathrm{S}^{7-}$ ${ }^{8}$. Corroborating with such information, $44 \%$ of the students answered correctly the question that referred to Sickle Cell Anemia etiology.

In relation to Sickle Cell Anemia oral manifestations, the success rate was even smaller. Only $30.4 \%$ of the research subjects agreed with the alternative in which the main signs of the disease are mucosa paleness, yellow coloration of tissues, radiographic alterations, delay of teeth eruption, and enamel and dentine disorder, malocclusion, hyper-cementosis and a degree of periodontitis uncommon in children ${ }^{9-10}$.

In some cases, the pulp chamber shows calcifications similar to denticles that might be the result of blood vessel thrombosis that irrigate the affected area. The most common oral complications are due to the development of sickle cells with ischemia of the bone marrow and adjacent bone structures. Among them, there are osteomyelitis, nerve neuropathies of the mandibular and mentonian nerves, asymptomatic pulp necrosis and orofacial pain². 
Hemophilia is a congenital hereditary disease. Hemophilia A or classic is the result of deficiency of coagulation factor VIII, while hemophilia B is caused by a qualitative or quantitative alteration of the coagulation factor IX. Both present themselves with higher prevalence in the male gender. Their bearers suffer hemorrhages that are difficult to control and they can occur spontaneously as well as through small traumatisms $s^{1,11-12}$. Although only $27.4 \%$ marked this alternative which contained the information, a slightly higher number knew Hemophilia oral manifestations.

Some Hemophilia oral manifestations are: petechiae and ecchymosis localized on the mucosa surface; prolonged gingival bleeding, spontaneous or provoked by traumatism and, rarely, hemarthrosis of temporomandibular articulation ${ }^{13-14}$. In this sense, $38.1 \%$ of the academics agreed with such information.

Leukemia is a group of complex malignant cells with differences among them, characterized by excessive and progressive production of leukocytes that appear in the blood in immature forms ${ }^{13}$. According to the original cell, leukemia can be classified as myeloid or lymphocytic. Both can be acute or chronic, thus there are four types of Leukemia ${ }^{14}$.

Oral complications due to leukemia can be classified in primary, secondary and tertiary. The primary lesions are the result of oral tissues infiltration by leukemic cells, standing out gingival hyperplasia and gingivitis. The secondary lesions are associated to thrombocytopenia and granulocytopenia that lead to a greater tendency of gingival bleeding and increase of susceptibility to infections, as candidiasis and herpes simplex; the tertiary lesions are consequences of the adopted therapeutics and are characterized by oral mucosa scurf and painful ulcerations which can generalize and xerostomia ${ }^{15}$.

Similar indexes of correct answers were obtained regarding Leukemia etiology and their buccal manifestation: $28 \%$ and $26.2 \%$, respectively.

Acknowledging the inception of a bleeding disturbance that may indicate the presence of a systemic pathological process might occur in odontological practice. Moreover, odontological prophylactic, restoring and surgical treatment of patients with hemorrhagic disturbance is better performed by professionals who have knowledge of pathology, complications and treatment options associated to these conditions.

A good anamnesis is essential to the dentist know the health status of the patient. When facing an abnormal situation indicating an hematological disfunction, the complementary exams are fundamental for a correct diagnosis. Almost all hemorrhagic disorders can be diagnosed performing the task of triage with platelets count, BT (bleeding time), PT (prothrombin time) and PTT (partial thromboplastin time). If the values found are not within normality, the patient must be referred to the hematologist ${ }^{16}$. Only $31.5 \%$ of the academics would request all these exams to evaluate the condition of a patient with abnormal bleeding after any cut or surgery.

Given what was exposed it is possible to infer that the knowledge of the academics attending the course of Dentistry at UESB regarding hematologic disorders is quite deficient. This result is in accordance with auto-perception over their knowledge level, given that despite $54.2 \%$ of academics assert that they are informed, most of them (79\%), considered that they are insufficiently informed.

It is concerning the fact that $45.8 \%$ of those who have not obtained this information, $70 \%$ pointed as a motive the lack of opportunity, given that they believe that the content will be approached in posterior semesters. Notwithstanding, although $67 \%$ students indicated classes as means to obtain information about hematologic disturbances and their implications in Dentistry, this content seems to be solely a roll of the discipline Integrated Clinic IV that approaches Dentistry for Patients with Special Needs. Although within the Hemopathies approached, Sickle Cell Anemia and Leukemia were not contemplated.

In the disciplines Oral Diagnosis and Odontological Clinic I, the content was approached sporadically in some semesters through seminar presentations and article readings. Information about etiology/ physiology regarding these disturbances were presented in Histology, Biochemistry, Pathology and Physiology. This explains the fact of lack of progress of knowledge throughout the semesters, given that for most students information was not communicated nor received.

Despite the few studies about this theme in the literature, studies performed with Iranian dentists points out that their knowledge about hemorrhagic disturbance is not at an ideal level and demands planning continued education courses $^{17-19}$. According to Robati \& Farokhi ${ }^{17}$, the lack of knowledge of dentists seems to result from the limited number of credits and insufficient hours dedicated to the course of "systemic diseases" (including blood and hemorrhagic diseases). This is why the curriculum review was approved, and the authors' expectations are that the knowledge level of future Dentistry students of the Iranian society be promoted through the implementation of a new curriculum.

Corroborating this idea, it is assumed that a reformulation of the curriculum will be necessary, given that teaching hematologic disorders in the Dentistry course at UESB 
was deficient, oscillating between semesters. Thus, these issues must be corrected so that knowledge be accumulated throughout the semester. Being part of a specific discipline, as asserted by $63 \%$ of students that didn't read this content nor distributed in several disciplines that are part of the course, this topic must be contemplated.

\section{CONCLUSION}

The level of knowledge of academics of Dentistry at UESB about hematological disturbances was insufficient. Moreover, It was noticed that gradual growth

\section{REFERENCES}

1. Haddad AS, Castilho AL. Doenças sistêmicas crônicas. In: Haddad AS. Odontologia para pacientes com necessidades especiais. São Paulo: Editora Santos; 2007. p. 263-76.

2. Brasil. Ministério da Saúde. Secretaria de Atenção à Saúde. Departamento de Atenção Especializada. Manual de saúde bucal na doença falciforme. Brasília: Ministério da Saúde; 2005.

3. Ministério da Saúde. Instituto Nacional de Câncer (INCA). Estimativa 2016: incidência de câncer no Brasil. Instituto Nacional de Câncer José Alencar Gomes da Silva. Rio de Janeiro: INCA; 2015.

4. Federação Brasileira de Hemofilia [homepage na internet]. Brasil possui a $3^{a}$ maior população de pessoas com hemofilia e outras coagulopatias hereditárias [citado 2014 Jan 8]. Disponível em: <www.hemofiliabrasil.org.br>.

5. Azevedo MTP, Castro AM, Oliveira FS, Mochidome FL, Novaes MSP, Wanderley, RL. Atendimento odontológico ao paciente com anemia falciforme: revisão de literatura. ROPE Rev Int Odonto-Psicol Odontol Pacientes Espec. 2006;2(7):77-81.

6. Galiza Neto GC, Pitombeira MS. Aspectos moleculares da anemia falciforme. J Bras Patol Med Lab. 2003;39(1):51-6. doi: 10.1590/S1676-24442003000100011

7. Diniz D, Guedes C, Barbosa L, Tauil PL, Magalhães I. Prevalência do traço e da anemia falciforme em recém-nascidos do Distrito Federal, Brasil, 2004 a 2006. Cad Saúde Públ. 2009:25:18894. doi: 10.1590/S0102-311X2009000100020

8. Pauling $L$, Itano $H A$, Singer JS, Wells IC. Sickle cell anemia, a molecular disease. Science. 1949;110:543-8. doi: 10.1126/ science. 110.2865 .543

9. Harold BS, McDonald DK, Miller RI. Dental management of patients with sickle cell disorders. J Am Dent Assoc. 1987:114:85-7. of knowledge throughout the semesters is polarized, especially in the 6th and 10th semesters. Transmission of information about this content occurred in most cases during classes of Oral Diagnosis, Odontological Clinic I and Integrated Clinic IV.

\section{Collaborators}

CA SILVA, CL SANTANA, RCDV ANDRADE, TL FRAGA e FO PRADO collaborated on the development of the research project, collecting and analyzing data and composing the manuscript.

10. Soni NN. Microradiographic study of dental tissues in sickle cell anaemia. Arch Oral Biol. 1966:2:561-4. doi: 10.1016/00039969(66)90221-4

11. Cerveró AJ, Roda RP, Bagán JV, Soriano YJ. Dental treatment of patients with coagulation factor alterations: an update. Oral Surg Oral Med Oral Pathol Oral Radiol Endo. 2007;12:380-7.

12. Prado MCP, Silveira FRX, Birman EG. Hemofilia: aspectos de interesse odontológico. RPG (USP). 1994;1(2):32-5.

13. Costa SS, Silva AM, Macedo IAB. Conhecimento de manifestações orais da leucemia e Protocolo de atendimento odontológico. Rev Odontol Univ Cid São Paulo. 2011;23(1):70-8

14. Davey FR, Hutchison RE. Diagnósticos clínicos e tratamento por métodos laboratoriais. 19a ed. São Paulo: Manole; 1999.

15. Segelman AE, Doku HC. Treatment of the oral complications of leukemia. J Oral Surg. 1977;35(6):469-77.

16. Israels S, Schwetz N, Boyar R, McNicol A. Bleeding disorders: characterization, dental considerations and management. J Can Dent Assoc. 2006;72(9):827.

17. Robati RMD, Farokhi MM. Evaluation the dentists' awareness of inherited bleeding disorders and anticoagulants in Shiraz. Iran J Ped Hematol Oncol. 2013; 3(4):159-163. 